ISSN = 1980-993X - doi:10.4136/1980-993X
www.ambi-agua.net
E-mail: ambi-agua@agro.unitau.br
Tel.: (12) 3625-4212

\title{
Sulfate and dissolved sulfide variation under low COD/Sulfate ratio in Up-flow Anaerobic Sludge Blanket (UASB) treating domestic wastewater
}

(http://dx.doi.org/10.4136/ambi-agua.849)

\author{
Eduardo Lucas Subtil ${ }^{1}$; Sérvio Túlio Alves Cassini ${ }^{2}$; Ricardo Franci Gonçalves ${ }^{2}$ \\ ${ }^{1}$ Centro Internacional de Referência em Reúso de Água, Universidade de São Paulo (USP), \\ ${ }^{2}$ Departamento de Engenharia Ambiental, Universidade Federal do Espírito Santo (UFES), \\ e-mail: ${ }^{1}$ eduardosubtil@gmail.com; ${ }^{2}$ scassini@npd.ufes.br; ${ }^{3}$ franci@npd.ufes.br
}

\begin{abstract}
In this study, the dynamics of sulfate reduction and dissolved sulfide generation $\left(\mathrm{S}^{2-}, \mathrm{HS}^{-}\right.$, $\mathrm{H}_{2} \mathrm{~S}_{\mathrm{aq}}$ ) in liquid phase was evaluated in an UASB reactor treating domestic wastewater with low COD/Sulfate content. The evaluation in the UASB reactor was performed at three sludge heights $(0.25,1.25,2.25$ taps $)$ and effluent of the reactor. Sulfate reduction was verified in the reactor, with an average reduction of $24 \%$ throughout the experiment period. However, the dissolved sulfide concentration in the reactor was not higher than $5.0 \mathrm{mg} \mathrm{S} \mathrm{S}_{\text {diss }} / \mathrm{L}$. The kinetic model of first order showed good fit to describe the sulfate reduction under different $\mathrm{COD} /$ sulfate ratio, with $\mathrm{K}_{1}^{\text {app }}$ between $2.94 \times 10^{-5} \mathrm{~s}^{-1}$ and $1.17 \times 10^{-5} \mathrm{~s}^{-1}$ with correlation coefficients for data over $91 \%$. The maximum rate to sulfate reduction was $18.0 \mathrm{mg} \mathrm{SO} \mathrm{S}^{2-} / \mathrm{L}^{2} \mathrm{~h}^{-1}$ and small variation in COD/sulfate ratio promotes a significant change both in sulfate and sulfide concentrations.
\end{abstract}

Keywords: COD/sulfate; dissolved sulfide; kinetics; sulfate reduction; UASB reactors.

\section{Variação de sulfato e sulfeto dissolvido sob baixas relações DQO/Sulfato em um Reator Anaeróbio de Manta de Lodo e Fluxo Ascendente (UASB) tratando esgoto sanitário}

\section{RESUMO}

Nesse estudo foi avaliado a dinâmica de redução de sulfato e da geração de sulfeto dissolvido $\left(\mathrm{S}^{2}, \mathrm{HS}^{-}, \mathrm{H}_{2} \mathrm{~S}_{\mathrm{aq}}\right.$ ) na fase líquida de um reator UASB tratando esgoto sanitário tipicamente doméstico com baixa relação DQO/sulfato. Para isso foram coletadas amostras do afluente e efluente, além de três alturas $(0,25 \mathrm{~m}, 1,25 \mathrm{~m}$ e $2,25 \mathrm{~m})$ ao longo do reator. Durante todo experimento foi observada redução de sulfato no reator UASB, com um valor médio de $24 \%$. Entretanto, a concentração de sulfeto dissolvido no efluente do reator não foi maior que $5,0 \mathrm{mg} \mathrm{S}_{\text {diss }} / \mathrm{L}$. O modelo cinético de primeira ordem apresentou um bom ajuste para descrever a redução de sulfato sob diferentes relações DQO/sulfato, com o valor de $\mathrm{K}_{1}{ }^{\text {app }}$ entre $2.94 \times 10^{-5} \mathrm{~s}^{-1}$ e $1.17 \times 10^{-5} \mathrm{~s}^{-1}$ com coeficiente de correlação para os dados superior a $91 \%$. A taxa máxima observada de redução de sulfato foi de $18.0 \mathrm{mg} \mathrm{SO}{ }_{4}{ }^{2-} / \mathrm{L} . \mathrm{h}^{-1}$ e pequenas variações na relação DQO/sulfato promoveu uma mudança significativa tanto na concentração de sulfato como na de sulfeto dissolvido.

Palavras-chave: DQO/sulfato; sulfeto dissolvido; cinética; redução de sulfato; reator UASB 


\section{INTRODUCTION}

Anaerobic treatment of domestic wastewater is not a new concept. However, since the first systems can only partially treat the sewage and, the effluent still contains high concentration of organic matter, suspended solids and nutrients, the interest for sewage treatment was over to aerobic treatment systems. With the advent of high rate anaerobic systems such as Up-flow Anaerobic Sludge Blanket Reactor (UASB), anaerobic contact process, anaerobic filter (AF) or fixed film reactors and fluidized bed reactors, which promote a good contact between the inflow wastewater and the micro-organisms at high concentration and consequently high organic matter removal at short retention times, the strategy for the treatment of sewage was shifted back to anaerobic process which has the advantages of low cost, energy recovery in the form of biogas, operational simplicity, low energy consumption, and low production of digested sludge (Khan et al., 2011; Lettinga, 2008; Chernicharo, 1997). In 1970s, due to the energy crisis and relatively less expensive treatment concept, the UASB process was recognized as one of the most feasible method for the treatment of sewage in developing tropical and sub-tropical countries like India, Brazil and Colombia where financial resources are generally scarce (Khan et al., 2011). Nowadays, it can be considered as an established technology and it is successfully used for the treatment of sewage and many kinds of industrial wastewaters (Lettinga and Hulshoff-Pol, 1991).

Despite the inherent advantages of high rate anaerobic system, the presence of sulfate $\left(\mathrm{SO}_{4}{ }^{2-}\right)$ represent a serious risk for the system, since the Sulfate Reducing Bacteria (SRB) can reduce sulfate to sulfide through a process denominated dissimilatory sulfate reduction (Postgate, 1984; Lens et al., 2001). This process is the main source of odorous compounds, mainly sulfide forms, in air phase during the anaerobic treatment of wastewater. Therefore the sulfate reduction in UASB reactors has been considered a negative side effect, since the production of sulfide causes several problems, such as toxicity (O'flaherty and Colleran, 2000), induced corrosion (Vincke et al., 2001), aggressive odors (Lens et al., 2001), increase of effluent COD and lowering the methane in biogas production (Lens et al., 1998).

Due to very favorable conditions for sulfate reduction in anaerobic reactors, it has been studied specially when the affluent is naturally enriched with sulfate forms (Kalyuzhnyi et al., 1997; Lens et al., 2002). The extent of sulfate reduction and organic matter mineralization depends upon several factors, including the sulfate concentration, wastewater composition, the ratio $\mathrm{COD} / \mathrm{SO}_{4}{ }^{2-}$ and environmental factors such as temperature and $\mathrm{pH}$ (Visser, 1996). Among these factors, the $\mathrm{COD} / \mathrm{SO}_{4}{ }^{2-}$ relationship has been considered one of the key factors when comparing the Methane Producing Microorganisms (MPM) and SRB (Colleran et al., 1995). Until recently, it was considered that a empirical affluent relationship COD/ $\mathrm{SO}_{4}{ }^{2-}>10$ was a strong prerequisite for successful anaerobic treatment because lower relationship values of $\mathrm{COD} / \mathrm{SO}_{4}{ }^{2-}<8$ were potentially inhibitory to methanogenesis and inducing excessive sulfide production in the anaerobic reactor although some authors (Hilton and Archer, 1988; Méndez et al., 1989; Shayegan et al., 2005) have reported a successful anaerobic treatment with $\mathrm{COD} / \mathrm{SO}_{4}{ }^{2-}$ values from 5 to 8 .

Thus, in order to increase the anaerobic wastewater treatment efficiency, with high sulfate concentration, it is necessary to know the dynamics of sulfate reduction in the liquid phase of the anaerobic reactor. The knowledge of kinetic parameters are extreme importance for modeling the biochemical processes allowing the substrate consumption, biomass growth at established conditions and reactor design and treatment efficiency. It should be emphasized that these parameters are not dependent only to sludge characteristics and substrate composition but also of environmental conditions for each biomass and wastewater composition. In this study, the sulfate reduction and dissolved sulfide $\left(\mathrm{S}^{2-}, \mathrm{HS}^{-}, \mathrm{H}_{2} \mathrm{~S}_{\mathrm{aq}}\right.$ ) in 
liquid phase was evaluated under low COD/Sulfate ratio by kinetics studies in an UASB reactor treating domestic wastewater in field scale.

\section{MATERIAL AND METHODS}

\subsection{Location and characteristics of UASB reactor}

The reactor is treating sewage from 800 inhabitants as part of compact treatment system with UASB followed by Submerged Aerobic Biofilter with main operational conditions summarized in Figure 1. The wastewater treatment plant is located at the Federal University of Espirito Santo, which is a mangrove area. This particular characteristic has a direct influence on the sulfate concentration in the wastewater due to infiltration in the sewerage system, causing odor problems in the treatment units (Santos et al., 2006). The UASB reactor in this study has the overall dimensions of $2.3 \times 2.3 \times 5.3 \mathrm{~m}(\mathrm{~L} \times \mathrm{W} \times \mathrm{H})$, with $28 \mathrm{~m}^{3}$ of utile volume and three height taps $(0.25,1.25$ and $2.25 \mathrm{~m})$ for sludge sampling. The wastewater treatment plant has been operating since 1997 and continues working until today. The study was conducted in the summer of 2007 on steady state condition.

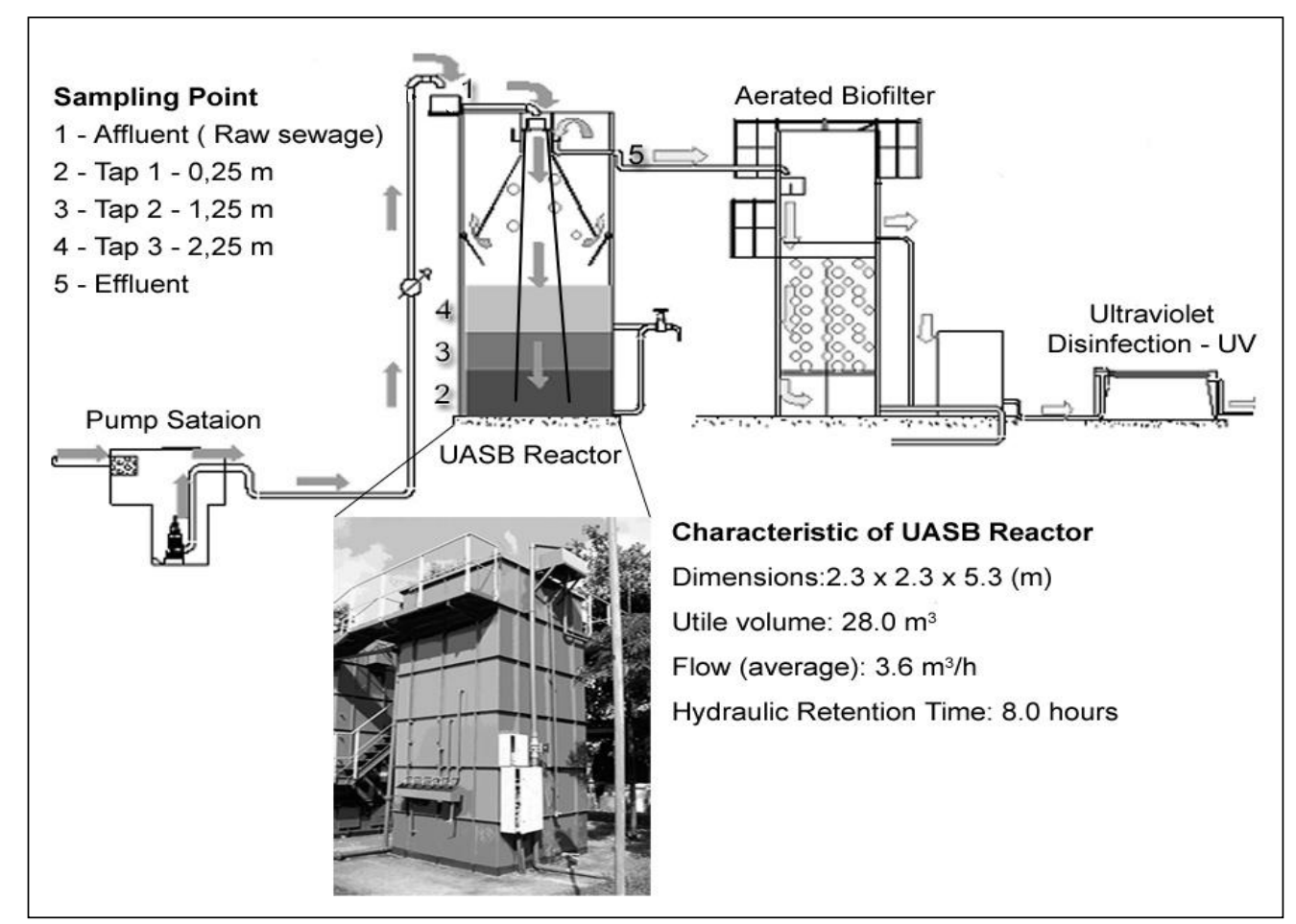

Figure 1. Layout of wastewater treatment plant system with sampling points and mainly characteristic of UASB reactor.

\subsection{Sampling and Analytical Procedures}

Samples were collected at 5 points of UASB reactor as following: 1) wastewater affluent at sand box; sludge samples at the top; 2) $0,25 \mathrm{~m}$; 3) $1,25 \mathrm{~m}$; 4) 2,25 m; and, 5) UASB effluent. The samples were collected considering the Hydraulic Retention Time (HRT) for each sampling point of reactor as shown in Table 1. The experiments were carried out between February and March totaling 20 samples for physical chemical parameters.

The Chemical Oxygen Demand (COD) was measured according to the Standard Methods for COD (APHA et al., 1995). A turbidimetric method was used to measure the concentration of sulfate (APHA et al., 1995). Prior to sulfate determination, suspended solids were removed from the sample by filtration. The absorbance of the sample was measured at a wavelength of 
$420 \mathrm{~nm}$. The absorbance of the sample was used to calculate the concentration of sulfate. For dissolved sulfide iodometric procedure was employed as reported in method 4500-B (APHA et al., 1995). The measured of $\mathrm{pH}$ and temperature was made with a multiparameter in situ.

Table 1: Sampling procedures for UASB reactor.

\begin{tabular}{l|c|l}
\hline \multicolumn{1}{c|}{ Sampling Point } & TDH (hours) & \multicolumn{1}{c}{ Parameters } \\
\hline Influent (Raw sewage) & $\mathrm{t}=0,0$ & $\mathrm{~T}^{\circ} \mathrm{C} ; \mathrm{pH}$; COD $_{\text {total }}$ Sulfate, Sulfide \\
Tap 1 - 0,25 m & $\mathrm{t}=0,4$ & $\mathrm{~T}^{\circ} \mathrm{C} ; \mathrm{pH}$; Sulfate, Sulfide \\
Tap 2-1,25 m & $\mathrm{t}=1,9$ & $\mathrm{~T}^{\circ} \mathrm{C} ; \mathrm{pH}$; Sulfate, Sulfide \\
Tap 3 - 2,25 m & $\mathrm{t}=3,4$ & $\mathrm{~T}^{\circ} \mathrm{C} ; \mathrm{pH}$; Sulfate, Sulfide \\
Effluent & $\mathrm{t}=8,4$ & $\mathrm{~T}^{\circ} \mathrm{C} ; \mathrm{pH}$; COD total, Sulfate, Sulfide \\
\hline
\end{tabular}

\subsection{Kinetics parameters estimation}

The kinetic studies here performed evaluated the sulfate reduction rates and kinetics constant (K1app) under different COD/sulfate ratio. A first-order kinetic model (Equation 1) was found to represent the kinetic behavior in all cases studied. The equation correlates the concentration of sulfate in the liquid phase with time. $\mathrm{K}_{1}{ }^{\text {app }}$ is the first-order apparent kinetic constant. Such a parameter is apparent, because it includes the phenomenon of mass transfer in the liquid and solid phases, besides the sulfate conversion rate.

$$
\left[\mathrm{SO}_{4}^{2-}\right]_{E f l .}=\left[\mathrm{SO}_{4}{ }^{2-}\right]_{\text {Infl. }} \times e^{k_{1}{ }^{a p p} . t}
$$

where:

$$
\begin{aligned}
& {\left[\mathrm{SO}_{4}{ }^{2-}\right]_{\text {Efl. }}=\text { Effluent sulfate concentration }(\mathrm{mg} / \mathrm{L}) ;} \\
& {\left[\mathrm{SO}_{4}{ }^{2-}\right]_{\text {Infl. }}=\text { Influent sulfate concentration }(\mathrm{mg} / \mathrm{L}) ;} \\
& \mathrm{K}_{1}{ }^{\text {app }}=\text { kinetics constant }\left(\mathrm{s}^{-1}\right) ; \\
& \mathrm{t}=\text { Hydraulic Retention Time. }
\end{aligned}
$$

\section{RESULTS AND DISCUSSION}

\subsection{UASB Reactor performance}

The average values of main monitored parameters of UASB reactor are shown in Table 2. Considering the COD values, the raw sewage has a characteristic of weak wastewater but as regard to sulfate concentration it can be concluded that this sewage has higher average values than found for domestic sewage typically in the range of 20 to $50 \mathrm{mg} / \mathrm{L}$ (Metcalf \& Eddy, 2003). The average efficiency or organic matter removal, of UASB reactor, expressed

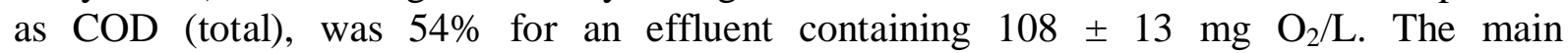
characteristics of raw sewage and UASB reactor effluent used in this study are illustrated in Table 2.

Figure 2 shows the plots of $\mathrm{COD} / \mathrm{SO}_{4}{ }^{2-}$ ratio versus $\mathrm{COD}$ removal efficiency in the continuous UASB system under steady state condition. Based on data presented in Figure 2 it can be observed that the decrease of $\mathrm{COD} / \mathrm{SO}_{4}{ }^{2-}$ ratio had no effect on $\mathrm{COD}$ removal efficiency. This behavior can be attributed to the presence of the numerous of SRB, which can utilize organic carbon for new cells metabolite. Stoichiometrically $1.0 \mathrm{~g}$ COD is required for the reduction of $1.5 \mathrm{~g}$ sulfate and thus both $\mathrm{COD}$ and $\mathrm{SO}_{4}{ }^{2-}$ are removed in the process (Metcalf \& Eddy, 2003). 
SUBTIL, E. L.; CASSINI, S. T. A.; GONÇALVES, R. F. Sulfate and dissolved sulfide variation under low COD/Sulfate ratio in Up-flow Anaerobic Sludge Blanket (UASB) treating domestic wastewater. Ambi-Agua, Taubaté, v. 7, n. 1, p. 130-139, 2012. (http://dx.doi.org/10.4136/ambi-agua.849)

Table 2. Average values of raw sewage and UASB Reactor effluent.

\begin{tabular}{lcc}
\hline Parameter & Raw Sewage & Effluent \\
\hline Temperature $\left({ }^{\circ} \mathrm{C}\right)$ & $31 \pm 1,8$ & $30 \pm 1,5$ \\
pH & $6.9 \pm 0,8$ & $6.7 \pm 0.6$ \\
Total COD $(\mathrm{mg} / \mathrm{L})$ & $235 \pm 27$ & $108 \pm 13$ \\
Sulfate $(\mathrm{mg} / \mathrm{L})$ & $151 \pm 13$ & $114 \pm 8$ \\
Sulfide $(\mathrm{mg} / \mathrm{L})$ & $1.4 \pm 0.3$ & $3.4 \pm 0.7$ \\
\hline
\end{tabular}

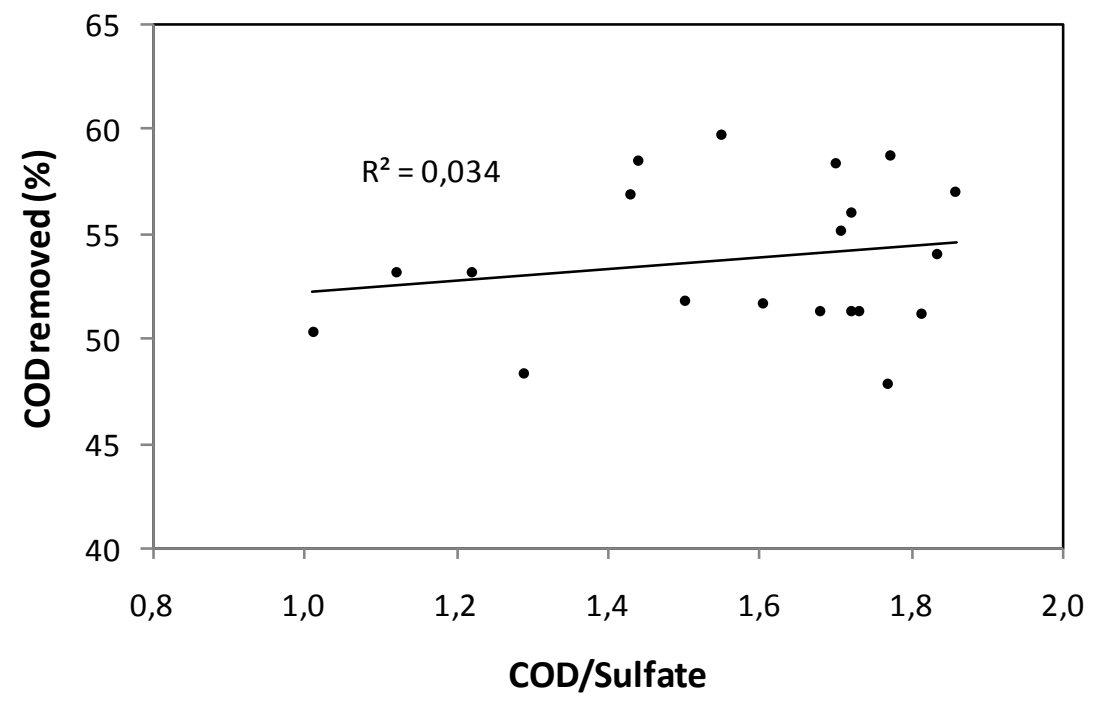

Figure 2. Relationship between COD/SO4 ratio and COD removal.

The sulfate and dissolved sulfide concentration profile along the reactor were evaluated in the 8,0 hours corresponding to the HRT values at each point as showed in Figure 3 . The overall results showed that $24 \%$ of sulfate was reduced in the reactor. In fact, the sulfate reduction appears to be more effective between the reactor heights of $1,25 \mathrm{~m}$ and 2,25 m corresponding to HRT of 1,9 and 3,4 h. Although the sulfide production was apparently linear with the increasing sulfate reduction (Figure 4), the experimental sulfide production differs from the theoretical values, considering the total sulfate remove being converted into sulfide in the liquid phase. The theoretical total conversion of sulfate to sulfide shows a stoichiometry coefficient of $0,33 \mathrm{mg}$ sulfide production per $\mathrm{mg} \mathrm{SO}_{4}{ }^{2-}$ reduced and the evaluated experimental linear regression coefficient was $0,031 \mathrm{mg}$ dissolved sulfide per $\mathrm{mg} \mathrm{SO}_{4}{ }^{2-}$ (Figure 4).

The sulfide produced inside the bioreactor may be present in different forms such as undissociated hydrogen sulfide in liquid and gas phase, $\mathrm{HS}^{-}$and $\mathrm{S}^{2-}$. So the measured hydrogen sulfide, which corresponds to various forms of sulfide in the liquid phase, may not account for the total sulfide produced. Based on these observations, it should be emphasized that sulfate and dissolved sulfide in the UASB reactor can follow different routes and could be lost or non detected (Speece, 1996). In the case of sulfate, it can follow the assimilative route of sulfide becoming a integral part of biomass (organic S). In the dissimilative route the sulfate is released in the medium as sulfide. Thus, the released sulfide can be precipitated by metal ions on liquid phase or accumulating in the sludge blanket (Jong and Parry, 2003) or escaping to aerial phase and apparently lost from aqueous phase. 


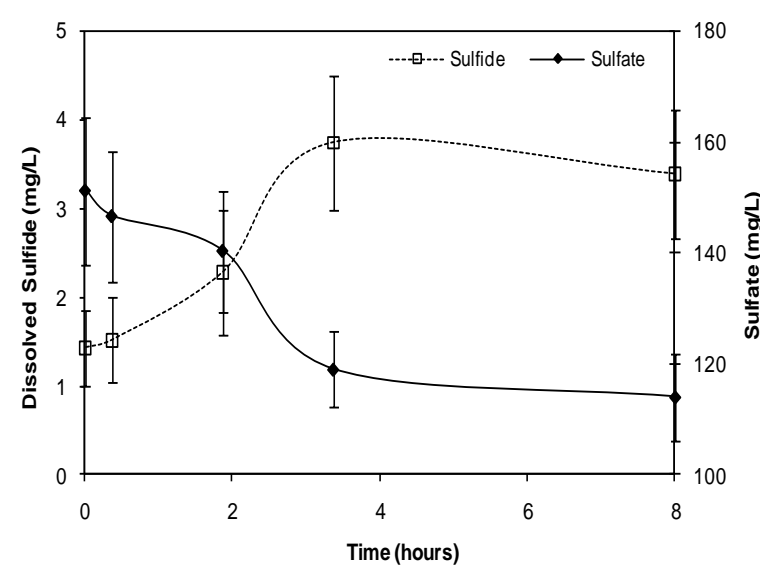

Figure 3. Temporal profile of sulfate and sulfide concentration in UASB reactor.

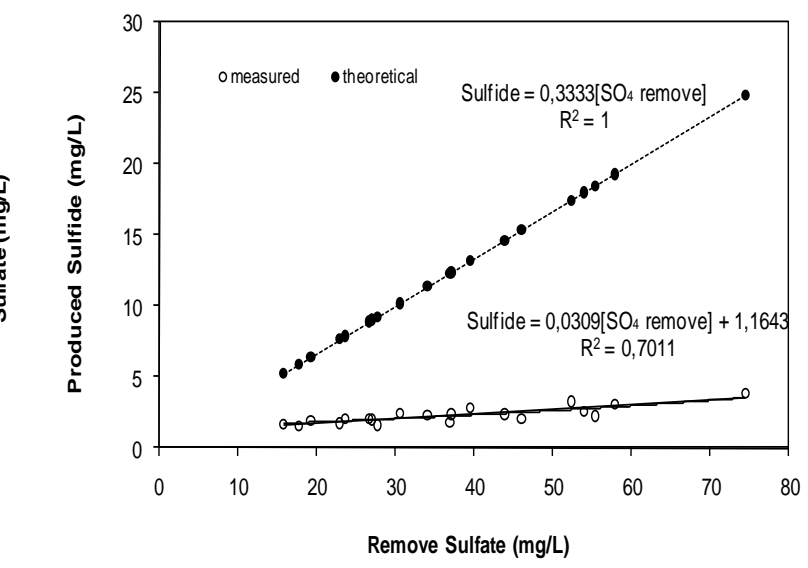

Figure 4. Relationship between sulfate removal $(\%)$ and sulfide production $(\mathrm{mg} / \mathrm{L})$

\subsection{Sulfate reduction at different feed $\mathrm{COD} / \mathrm{SO}_{4}{ }^{2-}$}

Another investigated parameter was the relationship COD/sulfate in the reduction process. A first-order kinetic model was found to represent the kinetic behaviour in all cases studied. Therefore, exponential expressions were adjusted to all the profiles with good correlation coefficient, as showed in Table 3 and Figure 5. The equation correlates the concentration of sulfate in the effluent with time and with the initial concentration of the sulfate in the liquid phase. Can be observed a tendency in $\mathrm{K}_{1}{ }^{\text {app }}$ values with small changes in $\mathrm{COD} / \mathrm{Sulfate}$ ratio where the increased of $\mathrm{K}_{1}{ }^{\text {app }}$ was observed with low values of COD/Sulfate (Figure 6). It is shown that a small variation in $\mathrm{COD} /$ sulfate ratio (1.1 to 1.85) promotes a significant change in sulfate reduction as exemplified by the $45 \%$ to $10 \%$ of sulfate removal. Therefore, the overall conversion rates were mainly influenced by the biochemical reactions rates, which need to be considered in the sulfide production in UASB reactor.
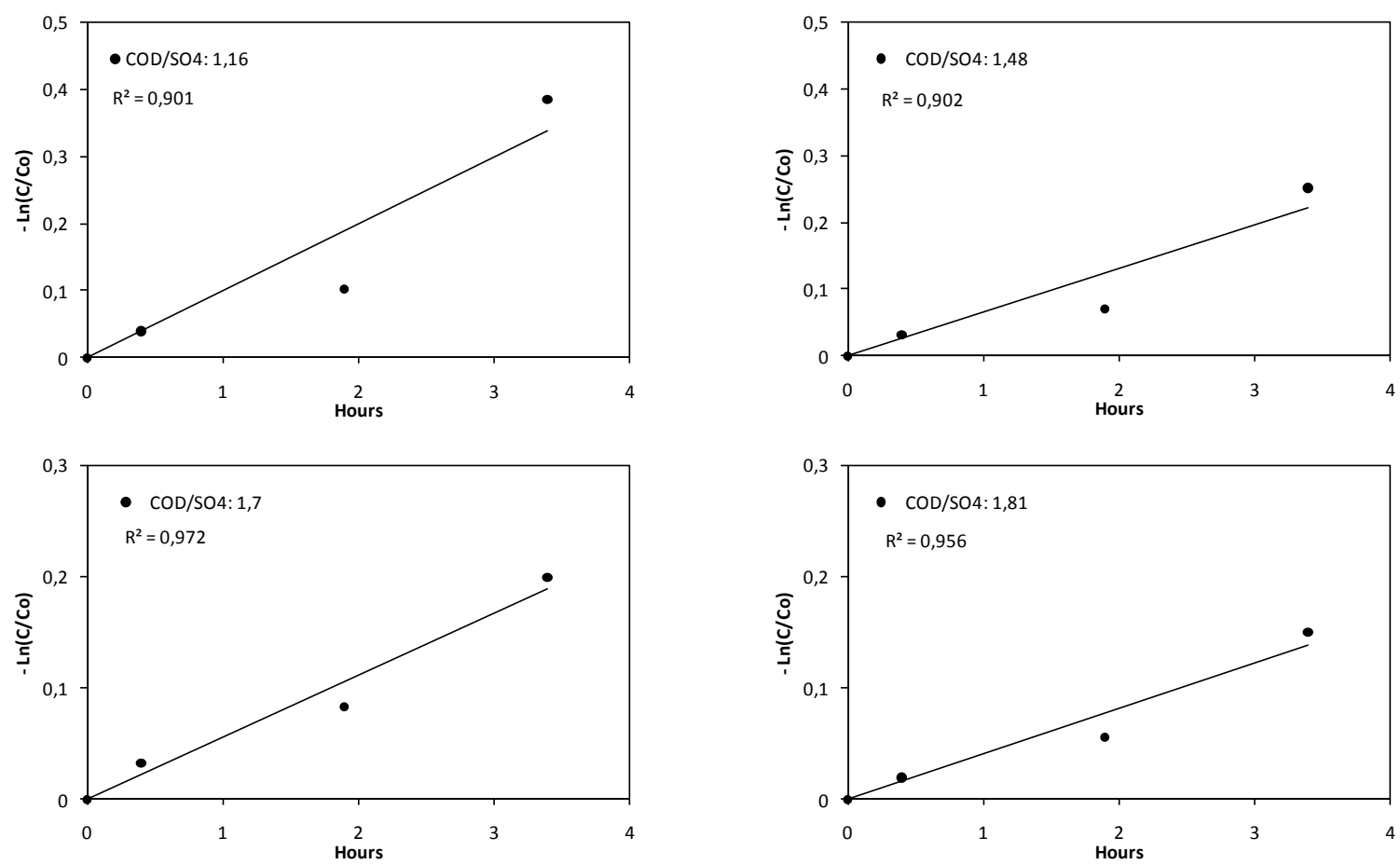

Figure 5. Sulfate reduction in UASB reactor under different COD/Sulfate ratios. 
The influent $\mathrm{COD} / \mathrm{SO}_{4}{ }^{2-}$ ratio has been reported by several authors to significantly affect the metabolic pathways of SRB (Colleran et al., 1995; O'Reilly and Colleran, 2006). At lower $\mathrm{COD} / \mathrm{SO}_{4}{ }^{2-}$ ratios, organic matter degrading SRM might become in competitive advantage with syntrophs, which is generally not the case for high $\mathrm{COD} / \mathrm{SO}_{4}{ }^{2-}$ - ratios (sulfate limitation) (Visser, 1996). Therefore, higher sulfate reduction rates are possible at low COD/ $\mathrm{SO}_{4}{ }^{2-}$ ratios. However, the results presented in the literature on the effect of sulfate reduction on the anaerobic process are quite contradictory. While some reported on the competition between sulfate reducing and methanogenic microorganisms by acetate an hydrogen, other reported synthrophic relations between two groups. Choi and Rim (1991) observed that sulfate reducers and methane producers were very competitive at $\mathrm{COD} / \mathrm{SO}_{4}{ }^{2-}\left(\mathrm{mg} \mathrm{O} 2 / \mathrm{mg} \mathrm{SO}_{4}{ }^{2-}\right.$ ) ratio of 1.7 to 2.7. They also observed that methane producers predominated at high $\mathrm{COD} /$ $\mathrm{SO}_{4}{ }^{2-}$ ratios, while sulfate reducers predominated when the value of this ratio decreased. On the contrary, Prasad et al. (1988) observed that methanogenic bacteria prevailed over sulfate reducing bacteria for $\mathrm{COD} / \mathrm{SO}_{4}{ }^{2-}$ ratio around one.

Besides the $\mathrm{COD} / \mathrm{SO}_{4}{ }^{2-}$ ratio, the $\mathrm{pH}$ holes an important play in the competition between SRB and methanogenic microorganisms. The results obtained from Visser et al. (1993) with the three reactors showed that the amount of organic COD removed via either sulphate reduction or methanogenesis is strongly influenced by the $\mathrm{pH}$ at which the reactor is operated. The removal efficiencies obtained by these authors in the reactors, as a function of the effluent $\mathrm{pH}$, showed it is clear that at $\mathrm{pH}>8$ sulphate reduction becomes predominant, whereas, apparently, at $\mathrm{pH}$ 6.75-7.5 a kind of steady state is established between methane production and sulphate reduction. It may be the cause for a small sulphate reduction in the UASB reactor as a consequence of the low effluent $\mathrm{pH}$ (Table 2).

Table 3. Expressions adjusted to the experimental sulfate profiles for each COD/Sulfate ratio and respective correlation coefficients $\left(\mathrm{R}^{2}\right)$.

\begin{tabular}{ccccc}
\hline COD/Sulfate & First-Order Expression & $\mathbf{R}^{\mathbf{2}}$ & $\begin{array}{c}\mathbf{K}_{\mathbf{1}}{ }^{\text {app }} \mathbf{x 1 0} \\
\left(\mathbf{s}^{-\mathbf{1}}\right)\end{array}$ & $\begin{array}{c}\mathbf{r}_{\text {max. }} \\
\left(\mathbf{m g} / \mathbf{L} \cdot \mathbf{h}^{-\mathbf{1}}\right)\end{array}$ \\
\hline $1.16 \pm 0.06$ & {$\left[\mathrm{SO}_{4}\right]=168.97 . \mathrm{e}^{-0,1059 t}$} & 0.901 & 2.94 & 17.9 \\
$1.48 \pm 0.06$ & {$\left[\mathrm{SO}_{4}\right]=160.79 . \mathrm{e}^{-0,073 \mathrm{t}}$} & 0.902 & 2.03 & 11.7 \\
$1.70 \pm 0.04$ & {$\left[\mathrm{SO}_{4}\right]=147.93 . \mathrm{e}^{-0,056 \mathrm{t}}$} & 0.972 & 1.56 & 8.3 \\
$1.81 \pm 0.04$ & {$\left[\mathrm{SO}_{4}\right]=138.94 . \mathrm{e}^{-0,042 \mathrm{t}}$} & 0.956 & 1.17 & 5.8 \\
\hline
\end{tabular}

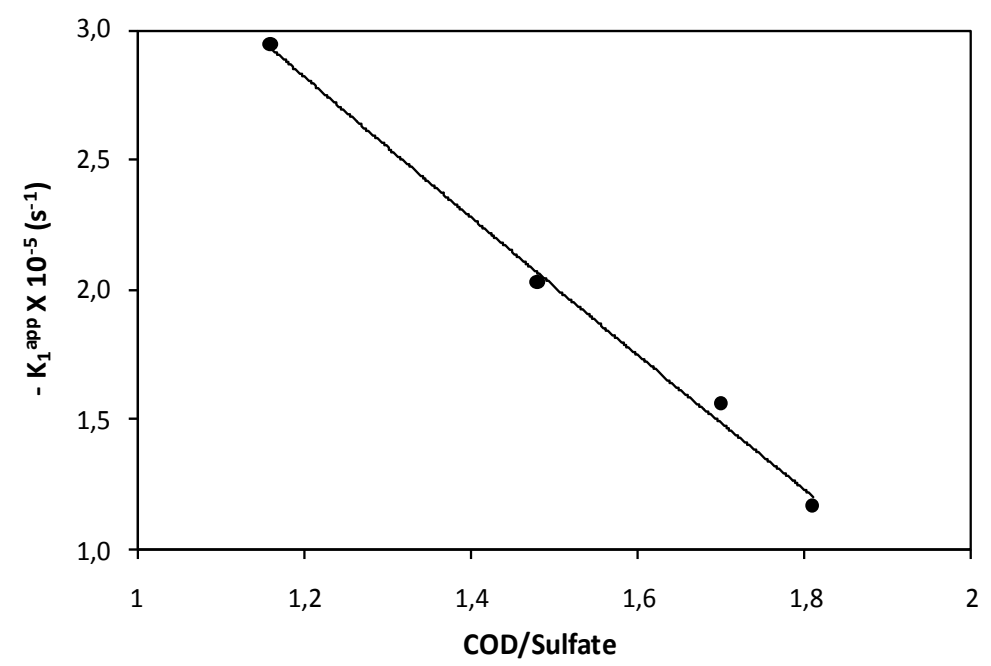

Figure 6. Influence of $\mathrm{COD} /$ Sulfate ratio on the first order kinetics constant $\left(\mathrm{K}_{1}\right)$ of the sulfate reduction. 
Kinetics studies of sulfate reduction with continuous stirring anaerobic reactors and suspended biomass have shown that sulfate reduction process is highly dependent upon the sulfate concentration (Moosa et al., 2002). It is reported that a increase of sulfate initial concentration of 1,0 to $5,0 \mathrm{~g} \mathrm{SO}_{4}{ }^{2-} / \mathrm{L}$ resulted in a significant increase in maximal reduction rate of 0,007 to $0,075 \mathrm{~g} \mathrm{SO}_{4}{ }^{2-} / \mathrm{L} . \mathrm{h}-1$ with no reported values for sulfide concentration in aqueous phase. Kinetic data for anaerobic reduction of sulfate as reported by different researchers are summarized in Table 4. The accurate assessment and comparison of the reported data is rather difficult. This is due to variations in microbial species and strains, experimental conditions such as sulfate concentration, $\mathrm{pH}$, temperature, metal concentrations and employment of different energy sources, as well as differences in configuration of the employed bioreactors.

Table 4: Comparison of kinetic data and manly characteristics of some anaerobic reactor reported by different author.

\begin{tabular}{|c|c|c|c|c|c|c|}
\hline $\begin{array}{c}\text { Temp. } \\
\left({ }^{\circ} \mathrm{C}\right)\end{array}$ & pH & $\begin{array}{c}\text { Flow rate } \\
\left(\mathbf{m}^{3} \cdot h^{-1}\right)\end{array}$ & $\begin{array}{c}\text { Initial sulfate } \\
\text { concentration } \\
(\mathrm{g} / \mathrm{L})\end{array}$ & $\begin{array}{c}\text { HRT } \\
\text { (h) }\end{array}$ & $\begin{array}{c}\text { Reduction } \\
\text { rate } \\
\left(\mathrm{g} / \mathrm{L} \cdot \mathrm{h}^{-1}\right) \\
\end{array}$ & Reference \\
\hline 25 & 4.5 & $1.56 \times 10^{-4}$ & 2.50 & 16.2 & 0.02 & Jong and Parry, 2003 \\
\hline- & 6.46 & - & 3.66 & - & 0.005 & Waybrant et al., 2002 \\
\hline- & 3.2 & & 2.00 & 12.0 & 0.132 & Glombitza, 2001 \\
\hline $23-26$ & 4.2 & $1.8 \times 10^{-4}$ & 0.9 & 6.6 & 0.072 & $\begin{array}{l}\text { Tsukamoto and Miller, } \\
1999\end{array}$ \\
\hline
\end{tabular}

\section{CONCLUSION}

Kinetic studies were found to be a useful tool to assess data of the influence of the $\mathrm{COD} /$ sulphate ratio on the anaerobic conversion process. In this study, the first-order kinetic model adequately represented the sulfate degradation rates. It is shown that a small variation in $\mathrm{COD} /$ sulfate ratio (1.1 to 1.85 ) promotes a significant change in sulfate reduction as exemplified by the $45 \%$ to $10 \%$ of sulfate removal. Furthermore, it was verified that the apparent kinetic parameters $\left(\mathrm{K}_{1}{ }^{\text {app }}\right)$ were affected by altering the COD/Sulfate ratio. The values of $\mathrm{K}_{1}{ }^{\text {app }}$ increased with low $\mathrm{COD} /$ sulphate ratios variation and this need to be considered in project of UASB reactor with low COD/sulfate effluent.

\section{REFERÊNCIAS}

American Public Health Association - APHA; American Water Works Association AWWA; Water Environment Federation - wef. Standard methods for the examination of water and wastewater. 20th ed. Washington DC, 1995.

CHERNICHARO, C. A. L. Reatores anaeróbios. Belo Horizonte: DESA/UFMG, 1997. 246p.

CHOI, E.; RIM, J. M. Competition and inibition of sulfate reducers and methane procucers in anaerobic treatment. Water Science \& Technology, v. 23, n. 7, p. 1259-64, 1991.

COLLERAN, E.; FINNEGAN, S.; LENS, P. N. L. Anaerobic treatment of sulphatecontaining waste streams. Antonie van Leeuwenhoek, v. 67, n. 1, p. 29-46, 1995. http://dx.doi.org/10.1007/BF00872194 
GLOMBITZA, F. Treatment of acid lignite mine flooding water by means of microbial sulfate reduction. Waste Management, v. 21, n. 2, p. 197-203, 2001. http://dx.doi.org/10.1016/S0956-053X(00)00061-1

HILTON, M. G.; ARCHER, D. B. Anaerobic digestion of a sulfate rich-molasses wastewater: inhibition of hydrogen sulfide production. Biotechnology and Bioengineering, v. 31, n. 8, p. 885-8, 1988. http://dx.doi.org/10.1002/bit.260310817

JONG, T.; PARRY, D. L. Removal of sulfate and heavy metals by sulfate reducing bacteria in short-term bench scale upflow anaerobic packed bed reactor runs. Water Research, v. 37, p. 3379-89, 2003. http://dx.doi.org/10.1016/S0043-1354(03)00165-9

KALYUZHNYI, S. V.; FRAGOSO, C. De LEON; MARTINEZ, J. R. Biological sulfate reduction in a UASB reactor fed with ethanol as the electron donor. Mikrobiologiya, v. 66, n. 5, p. 562-67, 1997.

KHAN, A. A.; GAUR, R. Z.; TYAGI, V. K.; KHURSHEED, A.; LEWB, B.; MEHROTRA, I. et al. Sustainable options of post treatment of UASB effluent treating sewage: a review. Resources, Conservation and Recycling, v. 55, n. 12, p. 1232-51, 2011. http://dx.doi.org/10.1016/j.resconrec.2011.05.017

LENS, P. N. L.; VISSER, A.; JANSEN, A. J. H.; HULSHOFF-POL, L. W.; LETTINGA, G. Biotechnological treatment of sulphate-rich wastewaters. Critical Reviews in Environmental Science and Technology, v. 28, n. 1, p. 41-88, 1998. http://dx.doi.org/10.1080/10643389891254160

LENS, P. N. L.; KUENEN, J. G. The biological sulfur cycle: novel opportunities for environmental biotechnology. Water Science and Technology, v. 44, n. 8, p. 57-66, 2001 .

LENS, P. N. L.; VALLEROL, M.; ESPOSITO, G.; ZANDVOORT, M. Perspectives of sulfate reducing bioreactors in environmental biotechnology. Reviews in Environmental Science and Biotechnology, v. 1, n. 4, p. 311-25, 2002. http://dx.doi.org/10.1023/A:1023207921156

LETTINGA, G.; HULSHOFF-POL, L. W. UASB - Process design for various types of wastewaters. Water Science and Technology, v. 24, n. 8, p. 87-107, 1991.

LETTINGA, G. Towards feasible and sustainable environmental protection for all. Aquatic Ecosystem Health \& Management, v. 11, n. 1, p. 116-24, 2008.

MÉNDEZ, R.; TEN-RUMMELER, E.; HULSHOFF POL, L. W. Start up of UASB reactors treating sucrose-containing substrate with a low cod/sulfate ratio. Environmental Technology Letters, v. 10, n. 1, p. 83-90, 1989. http://dx.doi.org/10.1080/09593338909384721

METCALF \& EDDY INC. Wastewater engineering: treatment, disposal and reuse. 4. ed. New York: McGraw-Hill Books, 2003. 1815p.

MOOSA, S.; NEMATI, M.; HARRISON, S. T. L. A kinetic study on anaerobic reduction of sulphate, part I: effect of sulphate concentration. Chemical Engineering Science, v. 57, p. 2773-80, 2002. http://dx.doi.org/10.1016/S0009-2509(02)00152-5 
O'FLAHERTY, V.; COLLERAN, E. Sulfur problems in anaerobic digestion. In: International Water Association. Environmental technologies to treat sulfur pollution: principles and engineering. London, 2000. p 467-89.

O'REILlY, C.; COLLERAN, E. Effect of influent $\mathrm{COD} / \mathrm{SO}_{4}{ }^{2}{ }^{-}$ratios on mesophilic anaerobic reactor biomass populations: physico-chemical and microbiological properties. FEMS microbiology ecology, v. 56, n. 1, p. 141-53, 2006. http://dx.doi.org/10.1111/j.1574-6941.2006.00066.x

POSTGATE, J. R. The sulphate reducing bacteria. 2nd ed. Cambridge: University Press, 1984.

PRASAD, D.; HENRY, G.; HAIK, S. Role of sulfate reducing bacteria in anaerobic treatment of landfill leachate. In: CSCE Annual Canadian Hydrotechnical Conference, 10., 1988, Vancouver. Proceedings... Vancouver: CSCE, 1988.

SANTOS, J. M.; SÁ, L. M.; REIS JÚNIOR, N. C.; GONÇALVES, R. F.; SIQUEIRA, R. N. Modelling hydrogen sulphide emission in a WWTP with UASB reactor followed by aerobic biofilters. Water Science and Technology, v. 54, n. 9, p. 173-80, 2006. http://dx.doi.org/10.2166/wst.2006.861

SHAYEGAN, J.; GHAVIPANJEH, F.; MIRJAFARI, P. The effect of influent COD and upward flow velocity on the behaviour of sulphate-reducing bacteria. Process Biochemistry, v. 40, n. 7, p. 2305-10, 2005. http://dx.doi.org/10.1016/j.procbio.2004.09.005

SPEECE, R. E. Anaerobic biotechnology for industrial wastewaters. 1. ed. Nashville: Archae Press, 1996. 394p.

TSUKAMOTO, T. K.; MILLER, G. C. Methanol as a carbon source for microbiological treatment of acid mine drainage. Water Research, v. 33, n. 6, p. 1365-70, 1999. http://dx.doi.org/10.1016/S0043-1354(98)00342-X

VINCKE, E.; BOON, N.; VERSTRAETE, W. Analysis of the microbial communities on corroded sewer pipes - a case study. Applied Microbiology and Biotechnology, v. 57, n. 5/6, p. 776-85, 2001. http://dx.doi.org/10.1007/s002530100826

VISSER, A.; GAO, Y.; LETTINGA, G. Effects of $\mathrm{pH}$ on methanogenesis and sulphate reduction in thermophilic $\left(55^{\circ} \mathrm{C}\right)$ UASB reactors. Bioresource Technology, v. 44, n. 2 , 113-21, 1993. http://dx.doi.org/10.1016/0960-8524(93)90184-D

VISSER, A.; HULSHOFF-POL, L. W.; LETTINGA, G. Competition of methanogenic and sulfidogenic bacteria. Water Science and Technology, v. 33, n. 3, p. 99-110, 1996. http://dx.doi.org/10.1016/0273-1223(96)00324-1

WAYBRANT, K. R.; PTACEK, C. J.; BLOWES, D. W. Treatment of mine drainage using permeable reactive barriers: column experiments. Environmental Science and Technology, v. 36, n. 6, p. 1349-56, 2002. http://dx.doi.org/10.1021/es010751g 